\title{
Permafrost Sub-grid Heterogeneity of Soil Properties Key for 3-D Soil Processes and Future Climate Projections
}

\author{
Christian Beer ${ }^{1,2 *}$ \\ ${ }^{1}$ Department of Environmental Science and Analytical Chemistry, Stockholm University, Stockholm, Sweden, ${ }^{2}$ Bolin Centre \\ for Climate Research, Stockholm University, Stockholm, Sweden
}

OPEN ACCESS

Edited by:

Michael Lehning,

École Polytechnique Fédérale de

Lausanne, Switzerland

Reviewed by:

Vincent Vionnet,

Centre d'Etudes de la Neige, France

Evgeny Andreevich Podolskiy,

Hokkaido University, Japan

Lukas Arenson,

BGC Engineering, Canada

*Correspondence:

Christian Beer

christian.beer@aces.su.se

Specialty section:

This article was submitted to

Cryospheric Sciences,

a section of the journal

Frontiers in Earth Science

Received: 11 April 2016 Accepted: 08 August 2016

Published: 23 August 2016

Citation:

Beer C (2016) Permafrost Sub-grid Heterogeneity of Soil Properties Key for 3-D Soil Processes and Future

Climate Projections.

Front. Earth Sci. 4:81.

doi: 10.3389/feart.2016.00081
There are massive carbon stocks stored in permafrost-affected soils due to the 3-D soil movement process called cryoturbation. For a reliable projection of the past, recent and future Arctic carbon balance, and hence climate, a reliable concept for representing cryoturbation in a land surface model (LSM) is required. The basis of the underlying transport processes is pedon-scale heterogeneity of soil hydrological and thermal properties as well as insulating layers, such as snow and vegetation. Today we still lack a concept of how to reliably represent pedon-scale properties and processes in a LSM. One possibility could be a statistical approach. This perspective paper demonstrates the importance of sub-grid heterogeneity in permafrost soils as a pre-requisite to implement any lateral transport parametrization. Representing such heterogeneity at the sub-pixel size of a LSM is the next logical step of model advancements. As a result of a theoretical experiment, heterogeneity of thermal and hydrological soil properties alone lead to a remarkable initial sub-grid range of subsoil temperature of $2^{\circ} \mathrm{C}$, and active-layer thickness of $150 \mathrm{~cm}$ in East Siberia. These results show the way forward in representing combined lateral and vertical transport of water and soil in LSMs.

Keywords: soil heterogeneity, carbon cycle, climate projection, permafrost, cryoturbation, soil temperature, ice content

\section{PARADIGM: VERTICAL PROCESSES CONTROL SOIL STATE}

Earth is a complex system and its compartments (atmosphere, ocean, land) are interacting with each other. Emergent patterns, such as the global air temperature at $2 \mathrm{~m}$ height are highly dependent on these interactions. Therefore, Earth system models (ESMs) aim to represent the most important processes of the different components and also their interactions. Atmospheric and oceanic processes have been considered in 3 spatial dimensions from the beginning. In contrast, soil processes such as soil organic matter dynamics are widely recognized as only temporal processes (chemical reaction type of process) without any spatial dimension (Schmidt et al., 2011; Lehmann and Kleber, 2015). This might be the case because of the much slower soil transport processes involved over decades to centuries (Braakhekke et al., 2014). However, observations show that soil organic matter usually follows a clear distribution of decreasing concentration with depth (Jobbágy and Jackson, 2000) which is driven by both transport processes, root litter distribution and climate (Jobbágy and Jackson, 2000; Davidson and Janssens, 2006). During the past 5 years this vertical distribution and underlying transport processes have been recognized by the scientific community 
and appropriate modeling schemes developed (Koven et al., 2009; Braakhekke et al., 2011; Tang et al., 2013; Ahrens et al., 2015). Still, our most advanced mechanistic understanding of soil state variable distribution is restricted to one spatial dimension (vertical) at a global scale. One reason for that is also the current paradigm in land surface modeling that only vertical processes determine the state of the system (Sellers et al., 1997).

\section{3-D SOIL PROCESSES DETERMINE SOIL STATE IN PERMAFROST REGIONS}

The inappropriateness of this oversimplification of soil processes becomes obvious when looking at high latitude terrestrial permafrost ecosystems. Soil particle distribution (stones, minerals, organic matter) in these areas follow 3-D patterns which are distinct from temperate or tropical soils (Ping et al., 2015). At the surface, patterned ground of various types and sizes can be observed, e.g., non-sorted circles (Ping et al., 2008, 2015; Walker et al., 2008; French, 2013). Below-ground cryostructures provide heterogeneity at $\mathrm{cm}$-scale (Ping et al., 2015) mainly due to ice lens formation (Rempel, 2007). In addition, the vertical distribution of organic matter shows remarkable peaks in the subsoil due to a process called cryoturbation (Ping et al., 2008; Harden et al., 2012; Hugelius et al., 2014; Gentsch et al., 2015). Here, cryoturbation is defined as the sum of soil movements due to frost action following French (2013). This vertical soil organic matter distribution is distinct from the monotonically decreasing carbon profile in temperate soils (Jobbágy and Jackson, 2000). The underlying forces for several processes leading to such large heterogeneity are freeze-thaw cycles and associated movement of water and soil particles in all three spatial dimensions (Yershov, 1998; Nicolsky et al., 2008; Woo, 2012). That means that $3-\mathrm{D}$ processes at the $\mathrm{cm}$-scale, such as water flux toward the freezing front, ice lens formation and frost sorting largely determine soil state heterogeneity in turbels (French, 2013). As a consequence, soil horizons may be reversed (cryoturbation) and with that organic rich material from the surface transported down to the subsoil (Bockheim, 2007; Ping et al., 2015), where it has been largely prevented from decomposition. Figure 1 demonstrate these combination of processes with a typical example. With decreasing active-layer thickness in time, such organic-rich horizons will be incorporated into permafrost (Ping et al., 2015). As a consequence, soil organic matter distribution in turbels cannot be explained by current models (Mishra et al., 2013) which account for only plant-soil and soil-soil interactions in the vertical domain. Therefore, with the current modeling tools in hand, we are unable to represent such vertical organic matter profiles and the large subsoil stocks in these soils (Ping et al., 2008; Hugelius et al., 2014). Hence, any attempt of mechanistically model the contribution of soil warming and permafrost thawing to ecosystem respiration change will fail, basically because the carbon profile is not represented. This is a problem of major importance for future climate projection because high latitude permafrost regions store massive amounts of soil organic matter compared to the atmosphere (Table 1), and climate has been changing

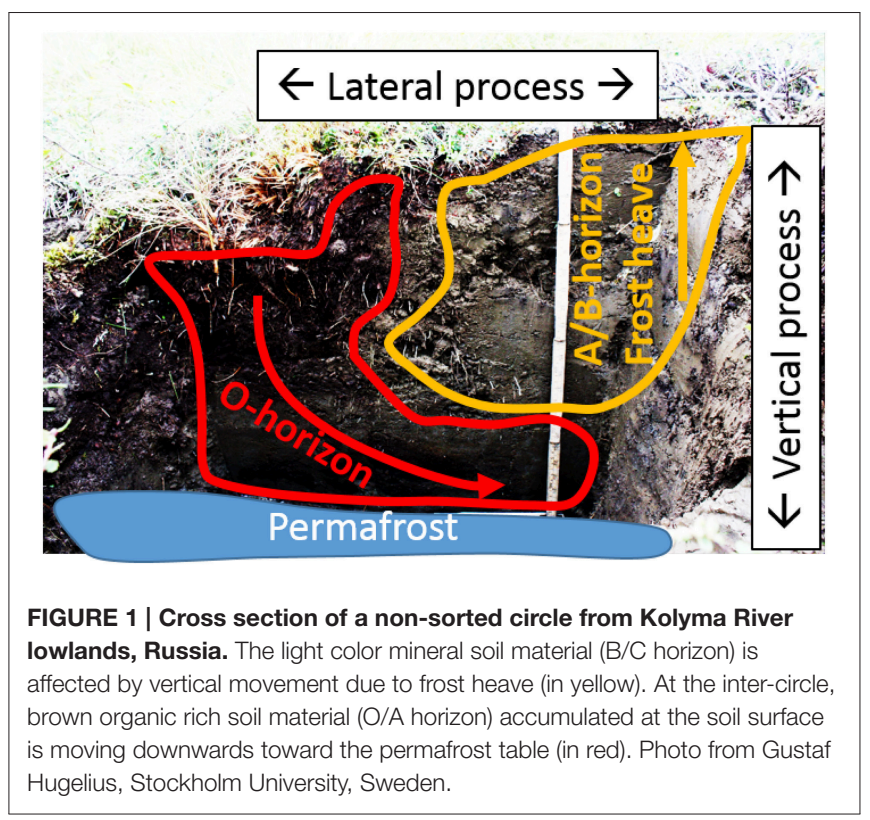

TABLE 1 | Comparison of carbon stocks in permafrost soils and in particular in cryoturbated soils (turbels) according to Hugelius et al. (2014) to carbon stocks in the atmosphere (Ciais et al., 2013).

\begin{tabular}{lc} 
Atmosphere & $\mathbf{5 9 0 + 2 4 0}$ \\
\hline $\begin{array}{l}\text { Turbels (cryoturbated) } \\
\text { Other permafrost soils }\end{array}$ & 476 \\
\hline Permafrost soils total & 977 \\
\hline $\begin{array}{l}\text { All units in Pg carbon. The two numbers presented for the atmosphere stand for the } \\
\text { historical part and the anthropogenic contribution, respectively. }\end{array}$
\end{tabular}

most in these regions providing the basis for a strong carbon cycle-climate feedback mechanism (McGuire et al., 2006, 2009; Beer, 2008; Heimann and Reichstein, 2008; Schuur et al., 2013, 2015). Another consequence of patterned ground formation is a resulting high heterogeneity of aerobic vs. anaerobic conditions in permafrost regions (Schuur et al., 2008) leading to distinct decomposition pathways to carbon dioxide and methane. As a result of anaerobic conditions, decomposition is much smaller than primary productivity resulting in peat accumulation hence carbon sequestration. Thawing permafrost may also result in a larger soil subsidence called thermokarst (Grosse et al., 2011) which can lead to lake development (Fedorov et al., 2014; Johansson et al., 2015) thereby altering completely landscape conditions.

\section{TOWARD REPRESENTING 3-D SUB-GRID PROCESSES IN EARTH SYSTEM MODELS}

These examples demonstrate how the overall land-atmosphere exchanges of heat, water and greenhouse gases in permafrost regions are largely dominated by soil state heterogeneity. 
Therefore, the assumption that all soil state variables are controlled by only vertical processes prevents a reliable process-based initialization of current soil water, ice and carbon contents, and any reliable projection of the future carbon balance, and hence climate. Instead, there is a strong need to represent heterogeneity and $3-\mathrm{D}$ processes at sub-grid level in land surface models. For a few specific meters, a mechanistic thermo-mechanical model (Nicolsky et al., 2008) could explain frost heaving when many parameters are adjusted to field conditions. The basis for frost heaving are small differences in soil properties and insulating layers that lead to an initial difference of temperature and water and ice profiles. With a water flux toward the freezing front (Wright, 1979; Yershov, 1998; Woo, 2012), with frost sorting of particles (French, 2013) and with ice lens formation during freeze-thaw cycles (Rempel, 2007), soil property and temperature profile differences become larger and non-sorted circles are forming. As a result, soil bulk density and organic layer depth varies at a centimeter scale, and in concert with changing active-layer thickness, soil horizons may be completely reversed. Such soil transport called cryoturbation is widely observed (Ping et al., 2008; Hugelius et al., 2010; Gentsch et al., 2015), however, it has to my knowledge never been simulated mechanistically, also not at the smallest spatial scale. Even if that was possible with a mechanistic model, e.g., following principles presented by Nicolsky et al. (2008), yet, we do not have any appropriate mathematical solution in hand for such 3 -D process at a landscape scale, that is as a sub-grid processes inside a $0.5^{\circ}$ grid cell. Transport processes can be represented by a few first terms of the master equation representing diffusion and advection processes (Koven et al., 2009; Braakhekke et al., 2011, 2014; Ahrens et al., 2015). Such approach can be used to simulate monotonically decreasing carbon content with depth (temperate soil) but this method completely fails when distinct large peaks of carbon concentration occur in a certain depth due to cryoturbation.

Controlled fine-scale experiments using fully mechanistic models, such as Nicolsky et al. (2008) are required in order to find any parametrization at broader scales for LSMs. This is because any observations of soil state variables, e.g., carbon or ice content will be confounded by many different factors not related to transport processes itself (evapotranspiration effect on soil moisture, decomposition effects on carbon content etc.). A valid concept for a parametrization in LSMs is still unclear and I can only speculate here. One initial idea could be to derive relationships of the diffusion coefficient to proxies for freezethaw cycle activity, e.g., the annual sum of latent heat flux, and notably, its spatial heterogeneity. Such dynamic coefficient may allow to represent an event-like vertical soil transport (Koven et al., 2009; Braakhekke et al., 2011, cf.). Such an approach of parameterizing 1-D processes based on fine-scale 3-D model results has been already applied in atmospheric modeling for representing thermal plumes (Rio and Hourdin, 2015). However, a more process-based approach considering explicitly lateral transport processes would be even more reliable in projecting the response of permafrost systems to climate change.

The underlying force for 3-D soil water fluxes and heat conduction will be always some initial heterogeneity of soil thermal and hydrological properties in addition to slope, snow distribution, and vegetation distribution leading to small-scale variations in soil climate as expressed by temperature, water and ice content. The temperature gradients are responsible for soil water content gradients from a saturated thawed part of the soil toward the freezing zone in which there is only little liquid water below the freezing point. This is the main force of the water flux toward the freezing zone and frost heave in autumn (Woo, 2012). As a result, soil structure and soil bulk density is altering at the centimeter scale (Rempel, 2007; French, 2013) which is then the main driver of particle movements (Nicolsky et al., 2008). It is interesting to note that, when considering water in all phases together, these freeze-thaw-induced lateral transport processes are not working in the direction of balancing spatial differences, as a diffusion process would balance concentration differences in fluid media. To illustrate the importance of an initial soil heterogeneity, one can consider this thought experiment: Imagine, in a 3-D soil system were all state variables identical. When applying any transport process equation, such as Richard's equation (Richards, 1931) for water flow, the resulting transport will be zero, i.e., ice lens formation or frost heave were not possible. Therefore, prior to any attempt of modeling 3-D fluxes of soil heat, water and matter, the way how soil heterogeneity can be represented in ESMs needs to be investigated. First respective research questions are: What are effects of soil property heterogeneity on soil state heterogeneity? Can we represent such heterogeneities in a land surface scheme as initial force for lateral processes?

\section{A FIRST STEP: SOIL HETEROGENEITY REPRESENTATION IN A LAND SURFACE SCHEME}

Land surface heterogeneity has traditionally been represented by a tiling approach of grid cells (Essery et al., 2003; Best et al., 2004): The grid cell is further divided into a number of tiles which are to represent homogeneous landscape types. Typically, the focus is on functional vegetation types (Woodward, 1987; Melton and Arora, 2014). However, some studies also consider subgrid heterogeneity of e.g., snow (Liston, 2004; Nitta et al., 2014; Gisnås et al., 2016). Usually, the same equations are applied but parameter values differ per tile. In order to address the questions raised above about pedon-scale soil property heterogeneity as the basis of fine-scale lateral transport processes, however, I suggest representing this heterogeneity using a statistical approach instead of a tiling concept, similar to the concept of representing a vegetation properties as distributions in the ED vegetation model (Moorcroft et al., 2001).

In a theoretical experiment, the permafrost-advanced land surface scheme JSBACH (Ekici et al., 2014) has been run over the Yakutia region in East Siberia using a high spatial resolution of $0.05^{\circ}$. Modeling protocol and climate and soil forcing data follows Ekici et al. (2014) except for deeper soil layers until $50 \mathrm{~m}$ and a longer spinup phase until equilibrium of state variables has been reached. The following properties have been considered in this study: thermal conductivity, heat 
capacity, volumetric soil porosity, saturated moisture potential, saturated hydraulic conductivity, the Clapp and Hornberger exponent b, volumetric soil field capacity, wilting point, soil pore size distribution index (Hagemann and Stacke, 2015, cf.). These properties at $0.05^{\circ}$ resolution are designed such that they represents a normal distribution at the original $0.5^{\circ}$ pixel size. That means that for each $0.5^{\circ}$ pixel 100 values have been randomly resampled such that the mean corresponds to the $0.5^{\circ}$ value with a standard deviation of $10 \%$ of that mean, which is a rather conservative estimate of soil property heterogeneity at pedon scale.

The resulting sub-grid distributions of soil state variables (subsoil temperature, water and ice content or active-layer thickness, ALT) at $0.5^{\circ}$ resolution have been then analyzed. Subsoil temperature represents a vertical average at $0.3-4 \mathrm{~m}$ in order to be most comparable with observation-based results of permafrost temperature presented in Beer et al. (2013). Figure 2 presents ranges of state variables within each $0.5^{\circ}$ grid cell. Just due to the heterogeneity of soil properties alone, subsoil temperature ranges from 0.5 to $2^{\circ} \mathrm{C}$, column-integrated water content ranges up to $30 \mathrm{~cm}$, and column-integrated ice content ranges up to $60 \mathrm{~cm}$. Active-layer thickness (ALT) even ranges up to $150 \mathrm{~cm}$ at this landscape scale Figure 2. Standard deviation of subsoil temperature falls between 0.1 and $0.7^{\circ} \mathrm{C}$ which is lower than observation-based results up to $2^{\circ} \mathrm{C}$ in the same area (Beer et al., 2013). The same is true for ALT for which model results suggest spatial standard deviations of $10-40 \mathrm{~cm}$ while observation-based evidence suggests up to $80 \mathrm{~cm}$ in Yakutia (Beer et al., 2013). The large initial heterogeneity in temperature, water and ice content only based on soil property heterogeneity demonstrates the potential for a representation of such 3-D processes that lead to cryoturbation as well as soil subsidence due to active-layer dynamics. Such 3-D processes will further increase the estimated initial heterogeneity of soil state variables resulting at observed levels. Still, the large heterogeneity of soil state variables in Figure 2 shows the way forward in representing important lateral processes. The results also demonstrate the need and the capability of representing distributions of soil state

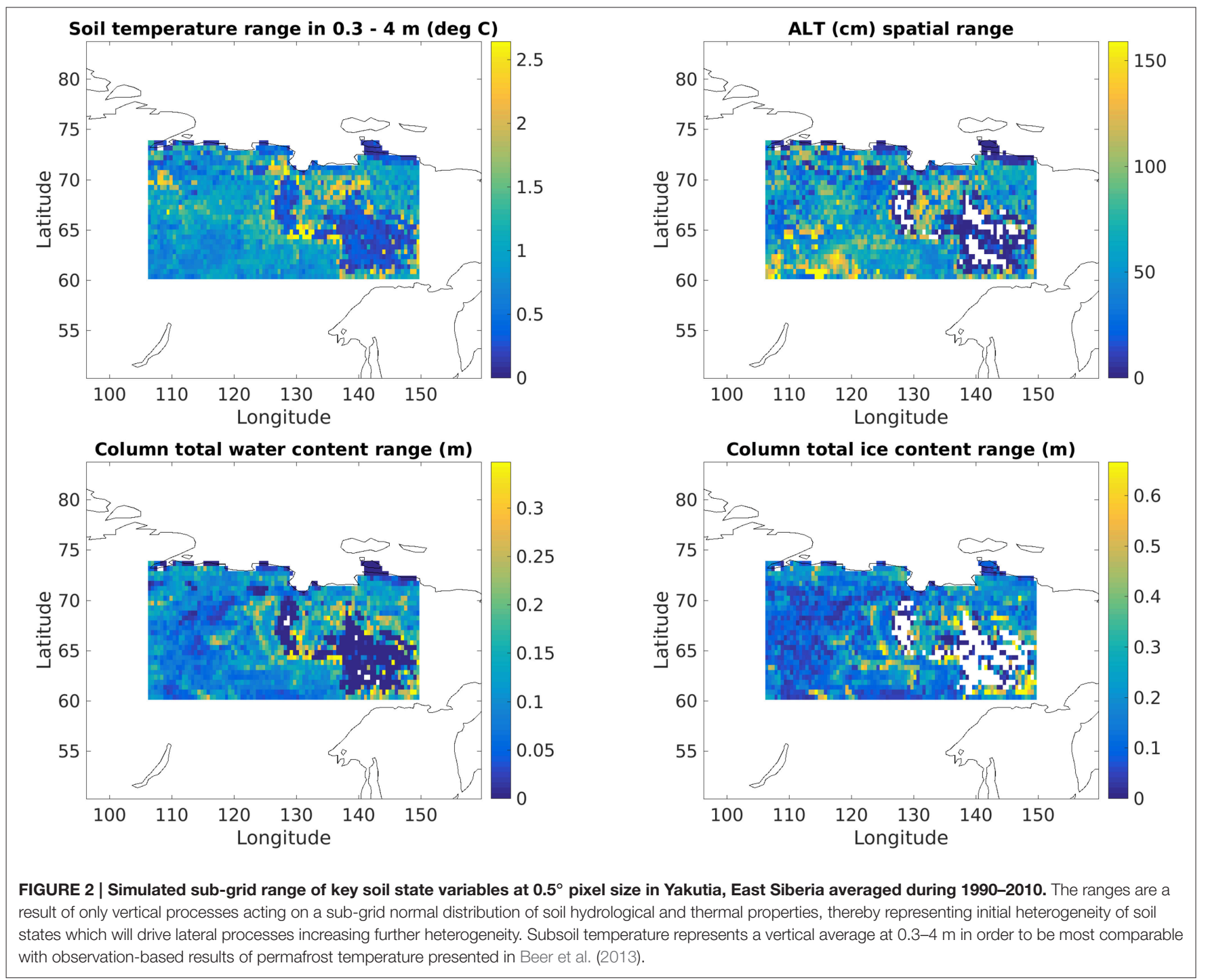


variables instead of considering only a mean at landscape scale in Earth system models.

\section{THE WAY FORWARD}

Land surface models function as the lower boundary condition for the atmosphere in Earth system models. After decades of model developments in order to mechanistically represent vascular plant functions (e.g., Sellers et al., 1997; Sitch et al., 2003), one recent and justified focus lies on advancements with respect to soil processes including freezing and thawing (Lawrence et al., 2008; Gouttevin et al., 2012; Ekici et al., 2014; Chadburn et al., 2015), organic matter transport, and decomposition (Guenet et al., 2013; Tang et al., 2013; Braakhekke et al., 2014; Ahrens et al., 2015). In particular for permafrost soils, the currently widely accepted assumption that only vertical processes govern soil state dynamics and land-atmosphere interactions does not hold. The massive amount of evidence for that and data available through field campaigns during the past decade (Harden et al., 2012; Hugelius et al., 2014; Ping et al., 2015) needs to be used in order to develop ideas on how to revise current land surface schemes and to include 3$\mathrm{D}$ processes leading to a sub-grid representation of soil state heterogeneity. In this respect, particular attention should be also paid on lateral water fluxes and related advective heat fluxes. Fully mechanistic thermo-mechanical models have been developed for applications over domains of a few meters (Nicolsky et al., 2008). Rigorous application of such fine-scale models over a range of soil conditions and artificially set climate conditions, together with field observations are thought to be the way forward to develop and parameterize freeze-thaw induced soil movement processes in land surface models. In addition, an introduction of 3-D soil heterogeneity into full-scale experimental studies (e.g., Sveen and Sørensen, 2013) is required for a deeper process understanding and for finding valid constrains on transport parameters. Such

\section{REFERENCES}

Ahrens, B., Braakhekke, M. C., Guggenberger, G., Schrumpf, M., and Reichstein, M. (2015). Contribution of sorption, DOC transport and microbial interactions to the $14 \mathrm{C}$ age of a soil organic carbon profile: insights from a calibrated process model. Soil Biol. Biochem. 88, 390-402. doi: 10.1016/j.soilbio.2015.06.008

Beer, C. (2008). Soil science: the arctic carbon count. Nat. Geosci. 1, 569-570. doi: 10.1038 /ngeo292

Beer, C., Fedorov, A. N., and Torgovkin, Y. (2013). Permafrost temperature and active-layer thickness of Yakutia with 0.5-degree spatial resolution for model evaluation. Earth Syst. Sci. Data 5, 305-310. doi: 10.5194/essd-5-3 05-2013

Best, M., Beljaars, A., Polcher, J., and Viterbo, P. (2004). A proposed structure for coupling tiled surfaces with the planetary boundary layer. J. Hydrometeorol. 5, 1271-1278. doi: 10.1175/JHM-382.1

Bockheim, J. (2007). Importance of cryoturbation in redistributing organic carbon in permafrost-affected soils. Soil Sci. Soc. Am. J. 71, 1335-1342. doi: 10.2136/ sssaj2006.0414N

Braakhekke, M. C., Beer, C., Hoosbeek, M. R., Reichstein, M., Kruijt, B., Schrumpf, M., et al. (2011). Somprof: a vertically explicit soil organic matter model. Ecol. Model. 222, 1712-1730. doi: 10.1016/j.ecolmodel.2011.02.015 model developments would allow for representing also other geomorphological processes related to freeze-thaw cycles in periglacial landscapes, such as solifluction or thermokarst, and even other lateral processes (e.g., erosion processes) being not related to freeze-thaw cycles. Developing basic concepts in this direction calls for a major community-wide effort. The first logical step toward this goal, the representation of sub-grid heterogeneity of soil state variables is straight forward.

\section{AUTHOR CONTRIBUTIONS}

$\mathrm{CB}$ designed the whole study, derived soil property forcing data at different spatial resolution, performed JSBACH model experiments, analyzed the model results, and wrote the manuscript.

\section{FUNDING}

CB acknowledges the Bolin Centre for Climate Research, Stockholm University, Sweden for contributing funding to his position.

\section{ACKNOWLEDGMENTS}

Model simulations were performed on resources provided by the Swedish National Infrastructure for Computing (SNIC) at Linköping University. Gustaf Hugelius, Stockholm University kindly provided a photo from a cross section of a nonsorted circle from the Kolyma River lowlands, Russia. I would like to thank the Land Department, Max Planck Institute for Meteorology, Hamburg, Germany for JSBACH code maintenance. Finally, I thank three anonymous reviewers and the editor Michael Lehning for useful and constructive comments which helped to improve a previous version of the manuscript.
Braakhekke, M. C., Beer, C., Schrumpf, M., Ekici, A., Ahrens, B., Hoosbeek, M. R., et al. (2014). The use of radiocarbon to constrain current and future soil organic matter turnover and transport in a temperate forest. J. Geophys. Res. Biogeosci. 119, 372-391. doi: 10.1002/2013jg002420

Chadburn, S. E., Burke, E. J., Essery, R. L. H., Boike, J., Langer, M., Heikenfeld, M., et al. (2015). Impact of model developments on present and future simulations of permafrost in a global land-surface model. Cryosphere 9, 1505-1521. doi: 10.5194/tc-9-1505-2015

Ciais, P., Sabine, C., Bala, G., Bopp, L., Brovkin, V., Canadell, J., et al. (2013). "Carbon and other biogeochemical cycles," in Climate Change 2013: The Physical Science Basis. Contribution of Working Group I to the Fifth Assessment Report of the Intergovernmental Panel on Climate Change, eds T. F. Stocker, D. Qin, G.-K. Plattner, M. Tignor, S. K. Allen, J. Boschung, A. Nauels, Y. Xia, V. Bex and P. M. Midgley (Cambridge, UK; New York, NY: Cambridge University Press), 465-570.

Davidson, E. A., and Janssens, I. A. (2006). Temperature sensitivity of soil carbon decomposition and feedbacks to climate change. Nature 440, 165-173. doi: 10.1038/nature04514

Ekici, A., Beer, C., Hagemann, S., Boike, J., Langer, M., and Hauck, C. (2014). Simulating high-latitude permafrost regions by the JSBACH terrestrial ecosystem model. Geosci. Model Dev. 7, 631-647. doi: 10.5194/gmd-7-631-2014 
Essery, R., Best, M., Betts, R., Cox, P. M., and Taylor, C. M. (2003). Explicit representation of subgrid heterogeneity in a GCM land surface scheme. J. Hydrometeorol. 4, 530-543. doi: 10.1175/15257541(2003)004<0530:EROSHI>2.0.CO;2

Fedorov, A., Gavriliev, P., Konstantinov, P., Hiyama, T., Iijima, Y., and Iwahana, G. (2014). Estimating the water balance of a thermokarst lake in the middle of the lena river basin, eastern siberia. Ecohydrology 7, 188-196. doi: 10.1002/eco.1378

French, H. M. (2013). The Periglacial Environment. Chichester: John Wiley \& Sons. doi: 10.1002/9781118684931

Gentsch, N., Mikutta, R., Alves, R. J. E., Barta, J., apek, P., Gittel, A., et al. (2015). Storage and transformation of organic matter fractions in cryoturbated permafrost soils across the Siberian Arctic. Biogeosciences 12, 4525-4542. doi: 10.5194/bg-12-4525-2015

Gisnås, K., Westermann, S., Schuler, T. V., Melvold, K., and Etzelmüller, B. (2016). Small-scale variation of snow in a regional permafrost model. Cryosphere 10, 1201-1215. doi: 10.5194/tc-10-1201-2016

Gouttevin, I., Krinner, G., Ciais, P., Polcher, J., and Legout, C. (2012). Multiscale validation of a new soil freezing scheme for a land-surface model with physically-based hydrology. Cryosphere 6, 407-430. doi: 10.5194/tc-6-407-2012

Grosse, G., Harden, J., Turetsky, M., McGuire, A. D., Camill, P., Tarnocai, C., et al. (2011). Vulnerability of high-latitude soil organic carbon in North America to disturbance. J. Geophys. Res. 116:G00K06. doi: 10.1029/2010JG001507

Guenet, B., Moyano, F. E., Vuichard, N., Kirk, G. J. D., Bellamy, P. H., Zaehle, S., et al. (2013). Can we model observed soil carbon changes from a dense inventory? A case study over England and Wales using three versions of the ORCHIDEE ecosystem model (AR5, AR5-PRIM and O-CN). Geosci. Model Dev. 6, 2153-2163. doi: 10.5194/gmd-6-2153-2013

Hagemann, S., and Stacke, T. (2015). Impact of the soil hydrology scheme on simulated soil moisture memory. Clim. Dyn. 44, 1731-1750. doi: 10.1007/s00382-014-2221-6

Harden, J. W., Koven, C. D., Ping, C.-L., Hugelius, G., David McGuire, A., Camill, P., et al. (2012). Field information links permafrost carbon to physical vulnerabilities of thawing. Geophys. Res. Lett. 39:L15704. doi: 10.1029/2012GL051958

Heimann, M., and Reichstein, M. (2008). Terrestrial ecosystem carbon dynamics and climate feedbacks. Nature 451, 289-292. doi: 10.1038/nature 06591

Hugelius, G., Kuhry, P., Tarnocai, C., and Virtanen, T. (2010). Soil organic carbon pools in a periglacial landscape: a case study from the central canadian arctic. Permafrost Periglacial Proc. 21, 16-29. doi: 10.1002/ppp.677

Hugelius, G., Strauss, J., Zubrzycki, S., Harden, J. W., Schuur, E. A. G., Ping, C.-L., et al. (2014). Estimated stocks of circumpolar permafrost carbon with quantified uncertainty ranges and identified data gaps. Biogeosciences 11, 65736593. doi: 10.5194/bg-11-6573-2014

Jobbágy, E. G., and Jackson, R. B. (2000). The vertical distribution of soil organic carbon and its relation to climate and vegetation. Ecol. Appl. 10, 423-436. doi: 10.1890/1051-0761(2000)010[0423:TVDOSO]2.0.CO;2

Johansson, E., Gustafsson, L.-G., Berglund, S., Lindborg, T., Selroos, J.-O., Liljedahl, L. C., et al. (2015). Data evaluation and numerical modeling of hydrological interactions between active layer, lake and talik in a permafrost catchment, western greenland. J. Hydrol. 527, 688-703. doi: 10.1016/j.jhydrol. 2015.05.026

Koven, C., Friedlingstein, P., Ciais, P., Khvorostyanov, D., Krinner, G., and Tarnocai, C. (2009). On the formation of high-latitude soil carbon stocks: effects of cryoturbation and insulation by organic matter in a land surface model. Geophys. Res. Lett. 36:L21501. doi: 10.1029/2009GL 040150

Lawrence, D., Slater, A., Romanovsky, V., and Nicolsky, D. (2008). Sensitivity of a model projection of near-surface permafrost degradation to soil column depth and representation of soil organic matter. J. Geophys. Res. 113:F02011. doi: 10.1029/2007JF000883

Lehmann, J., and Kleber, M. (2015). The contentious nature of soil organic matter. Nature 528, 60-68. doi: 10.1038/nature16069

Liston, G. E. (2004). Representing subgrid snow cover heterogeneities in regional and global models. J. Climate 17, 1381-1397.

McGuire, A. D., Anderson, L. G., Christensen, T. R., Dallimore, S., Guo, L., Hayes, D. J., et al. (2009). Sensitivity of the carbon cycle in the arctic to climate change. Ecol. Monogr. 79, 523-555. doi: 10.1890/08-2025.1
McGuire, A. D., Chapin, F., Walsh, J. E., and Wirth, C. (2006). Integrated regional changes in arctic climate feedbacks: implications for the global climate system. Annu. Rev. Environ. Resourc. 31, 61-91. doi: 10.1146/annurev.energy.31.020105.100253

Melton, J., and Arora, V. (2014). Sub-grid scale representation of vegetation in global land surface schemes: implications for estimation of the terrestrial carbon sink. Biogeosciences 11, 1021-1036. doi: 10.5194/bg-11-10 21-2014

Mishra, U., Jastrow, J., Matamala, R., Hugelius, G., Koven, C., Harden, J., et al. (2013). Empirical estimates to reduce modeling uncertainties of soil organic carbon in permafrost regions: a review of recent progress and remaining challenges. Environ. Res. Lett. 8:035020. doi: 10.1088/1748-9326/8/3/ 035020

Moorcroft, P. R., Hurtt, G., and Pacala, S. W. (2001). A method for scaling vegetation dynamics: the ecosystem demography model (ed). Ecol. Monogr. 71, 557-586. doi: 10.1890/0012-9615(2001)071[0557:AMFSVD]2.0.CO;2

Nicolsky, D. J., Romanovsky, V. E., Tipenko, G. S., and Walker, D. A. (2008) Modeling biogeophysical interactions in nonsorted circles in the low arctic. J. Geophys. Res. 113:G03S05. doi: 10.1029/2007JG000565

Nitta, T., Yoshimura, K., Takata, K., Oishi, R., Sueyoshi, T., Kanae, S., et al. (2014). Representing variability in subgrid snow cover and snow depth in a global land model: offline validation. J. Climate 27, 3318-3330. doi: 10.1175/JCLI-D-1300310.1

Ping, C. L., Jastrow, J. D., Jorgenson, M. T., Michaelson, G. J., and Shur, Y. L. (2015). Permafrost soils and carbon cycling. Soil 1, 147-171. doi: 10.5194/soil-1-1472015

Ping, C.-L., Michaelson, G. J., Jorgenson, M. T., Kimble, J. M., Epstein, H., Romanovsky, V. E., et al. (2008). High stocks of soil organic carbon in the north american arctic region. Nat. Geosci. 1, 615-619. doi: 10.1038/ngeo284

Rempel, A. W. (2007). Formation of ice lenses and frost heave. J. Geophys. Res. 112:F02S21. doi: 10.1029/2006JF000525

Richards, L. A. (1931). Capillary conduction of liquids through porous mediums. J. Appl. Phys. 1, 318-333. doi: 10.1063/1.1745010

Rio, C., and Hourdin, F. (2015). A thermal plume model for the convective boundary layer: representation of cumulus clouds. J. Atmospher. Sci. 72, 407-425. doi: 10.1175/2007JAS2256.1

Schmidt, M. W. I., Torn, M. S., Abiven, S., Dittmar, T., Guggenberger, G., Janssens, I. A., et al. (2011). Persistence of soil organic matter as an ecosystem property. Nature 478, 49-56. doi: 10.1038/nature10386

Schuur, E., Abbott, B., Bowden, W., Brovkin, V., Camill, P., Canadell, J., et al. (2013). Expert assessment of vulnerability of permafrost carbon to climate change. Climat. Change 119, 359-374. doi: 10.1007/s10584-013-0730-7

Schuur, E. A., Bockheim, J., Canadell, J. G., Euskirchen, E., Field, C. B., Goryachkin, S. V., et al. (2008). Vulnerability of permafrost carbon to climate change: implications for the global carbon cycle. BioScience 58, 701-714. doi: 10.1641/B580807

Schuur, E. A. G., McGuire, A. D., Schdel, C., Grosse, G., Harden, J. W., Hayes, D. J., et al. (2015). Climate change and the permafrost carbon feedback. Nature 520, 171-179. doi: 10.1038/nature 14338

Sellers, P. J., Dickinson, R. E., Randall, D. A., Betts, A. K., Hall, F. G., Berry, J. A., et al. (1997). Modeling the exchanges of energy, water, and carbon between continents and the atmosphere. Science 275, 502-509. doi: 10.1126/science.275. 5299.502

Sitch, S., Smith, B., Prentice, I. C., Arneth, A., Bondeau, A., Cramer, W., et al. (2003). Evaluation of ecosystem dynamics, plant geography and terrestrial carbon cycling in the LPJ dynamic global vegetation model. Global Change Biol. 9, 161-185. doi: 10.1046/j.1365-2486.2003. 00569.x

Sveen, S. E., and Sørensen, B. R. (2013). Establishment and instrumentation of a full scale laboratory for thermal and hygroscopic investigations of soil behavior in cold climates. Appl. Mech. Mater. 239, 827-835. doi: 10.4028/www.scientific.net/AMM.239-240.827

Tang, J., Riley, W., Koven, C., and Subin, Z. (2013). Clm4-betr, a generic biogeochemical transport and reaction module for clm4: model development, evaluation, and application. Geosci. Model Dev. 6, 127-140. doi: 10.5194/gmd6-127-2013

Walker, D. A., Epstein, H. E., Romanovsky, V. E., Ping, C. L., Michaelson, G. J., Daanen, R. P., et al. (2008). Arctic patterned-ground ecosystems: a synthesis 
of field studies and models along a North American arctic transect. J. Geophys. Res. 113:G03S01. doi: 10.1029/2007JG000504

Woo, M.-K. (2012). Permafrost Hydrology. Berlin; Heidelberg: Springer Science \& Business Media. doi: 10.1007/978-3-642-23462-0

Woodward, F. I. (1987). Climate and Plant Distribution. Cambridge, UK: Cambridge University Press.

Wright, R. K. (1979). Preliminary results of a study on active layer hydrology in the discontinuous zone at Schefferville, Nouveau-Québec. Géogr. Phys. Q. 33, 359-368.

Yershov, E. D. (1998). General Geocryology. Cambridge, UK: Cambridge University Press. doi: 10.1017/cbo9780511564505
Conflict of Interest Statement: The author declares that the research was conducted in the absence of any commercial or financial relationships that could be construed as a potential conflict of interest.

Copyright (c) 2016 Beer. This is an open-access article distributed under the terms of the Creative Commons Attribution License (CC BY). The use, distribution or reproduction in other forums is permitted, provided the original author(s) or licensor are credited and that the original publication in this journal is cited, in accordance with accepted academic practice. No use, distribution or reproduction is permitted which does not comply with these terms. 